\title{
Laser Speckle Imaging
}

National Cancer Institute

\section{Source}

National Cancer Institute. Laser Speckle Imaging. NCI Thesaurus. Code C116492.

A noninvasive, non-scanning optical imaging technique that provides full-field visualization

of blood flow to the tissue being imaged, which provides information about tissue

perfusion and the efficiency of disease treatment. 